\title{
Meta Analisis Efektivitas Model Problem Based Learning dan Problem Posing Terhadap Kemampuan Berpikir Kritis Siswa Sekolah Dasar Pada Pembelajaran Matematika
}

\author{
Jaya Yanti Nur Istiqomah ${ }^{1}$, Endang Indarini ${ }^{2}$ \\ Program Studi Pendidikan Guru Sekolah Dasar, Fakultas Keguruan Ilmu Pendidikan, Universitas Kristen Satya Wacana, \\ J1. Diponegoro No 52-60, Jawa Tengah, Indonesia \\ 292017148@student.uksw.edu
}

\begin{abstract}
The purpose of this study was to determine the comparability of Problem Based Learning and Problem Posing learning models to elementary students' mathematics critical thinking skills. The type of research used is Meta Analysis. The analytical data were obtained through online journals on google Scholar. Then a number of articles were selected, after selecting a sample of 20 articles to be analyzed. In order to know the difference in influence between the Problem Based Learning and Problem Posing models, it was carried out through the Ancova test. The results of the Effect Size test with the Problem Based Learning model and Problem Posing through Partial Eta Squared with a total of 0.789 with a Sig. amounting to 0,000 . The test results are able to have a significant effect on the critical thinking skills of elementary school students. Judging from the results of the Ancova test conducted on 20 articles on the Problem Based Learning learning model with an average number of posstest scores of 74.3620. While the Problem Posing's learning model has an average posstest score of 76.2580. It can be concluded that the Problem Posing learning model is counted more effective than the Problem Based Learning model.
\end{abstract}

Keywords: Problem Based Learning, Problem Posing, Critical Thinking, Elementary School

\begin{abstract}
Abstrak
Tujuan dari penelitian untuk mengetahui komparasi model pembelajaran Problem Based Learning dan Problem Posing terhadap kemampuan berpikir kritis matematika siswa sekolah dasar. Jenis penelitian yang digunakan adalah Meta Analisis. Data analisis didapatkan melalui jurnal online di google Cendekia. Kemudian dilakukan penyeleksian dari beberapa artikel, setelah dilakukan penyeleksian ditetapkan sampel sebanyak 20 artikel untuk dianalisis. Agar dapat diketahui perbedaan pengaruh antara model Problem Based Learning dan Problem Posing maka dilakukan melalui uji Ancova. Hasil dari uji Effect Size dengan model Problem Based Learning dan Problem Posing melalui Partial Eta Squared dengan jumlah 0,789 dengan nilai Sig. sebesar 0,000. Hasil uji tersebut mampu memberikan pengaruh tergolong efek besar terhadap kemampuan berpikir kritis matematika siswa sekolahb dasar. Dilihat dari hasil uji Ancova yang dilakukan pada 20 artikel terhadap model pembelajaran Problem Based Learning dengan jumlah rata-rata skor posstest sebesar 74,3620. Sedangkan model pembelajaran Problem Posing terdapat rata-rata skor posstest sebesar 76,2580, Hal ini dapat disimpulkan bahwa model pembelajaran Problem Posing terhitung lebih efektif dibandingkan model pembelajaran Problem Based Learning.
\end{abstract}

Kata kunci: Problem Based Learning, Problem Posing, Kemampuan Berpikir Kritis, Sekolah Dasar

Copyright (c) 2021 Jaya Yanti Nur Istiqomah, Endang Indarini

$\triangle$ Corresponding author: Jaya Yanti Nur Istiqomah

Email Address: 292017148@ student.uksw.edu (Jl. Diponegoro No 52-60, Jawa Tengah, Indonesia)

Received 17 Maret 2021, Accepted 18 Maret 2021, Published 22 Maret 2021

\section{PENDAHULUAN}

Pendidikan merupakan salah satu yang memiliki peran penting untuk perkembangan suatu Negara. Kualitas dari pendidikan suatu Negara dipengaruhi oleh beberapa factor. Seperti pengajar, sumber belajar, dan fasilitas belajar. Guru memegang peran penting untuk membantu meningkatkan kualitas pembelajaran di dalam kelas. Dalam meningkatkan kulaitas dalam mengajar, guru perlu melakukan hal inovatif dan kreatif di dalam kelas. Berdasarkan Permendikbud No. 22 Tahun 2016 dalam proses pembelajaran berpusat kepada siswa dengan menyelenggarakan pembelajaran yang menyenangkan, menantang, memotivasi, interaktif, inspiratif, memberikan ruang bagi prakarsa untuk 
membangun kreativitas yang sesuai dengan bakat, minat dan perkembangan fisik serta psikologi peserta didik.

Matematika merupakan cabang ilmu universal yang meliputi ide, gagasan, dan konsep abstrak yang tidak bisa lepas dari kehidupan manusia. Matematika berkembang luas dengan mencakup perkembangan sains dan teknologi (Wahyudi, 2002). Pembelajaran matematika ditingkat sekolah dasar diharapkan terjadinya penemuan kembali dalam penyelesaian masalah. penemuan ini maksudnya adalah bagaimana siswa dapat menemukan masalah dalam langkah langkah yang signifikan atau sesuai dengan urutan langkah langkah berpikir secara kritis. Menurut Brunner (dalam Heruman, 2013) menjelaskan bahwa pembelajaran matematika peserta didik di haruskan untuk dapat berpikir secara kritis dalam penyelesaian masalah atau berbagai sumber yang terkait penemuan dan penyelesaian masalah. Menurut Wahyudi dan Kriswand (2013) konsep matematika yang ditulis secara tersusun dalam bentuk simbol dengan Bahasa yang dipilih sangat mudah dipahami dan cermati.

Terdapat beberapa penelitian yang sudah pernah dilakukan dan sudah mengarah pada kemampuan berfikir kritis serta model pembelajaran. Tetapi masih belum ada penelitan terbaru dari meta analisis terutama pada kemampuan berfikir kritis matematika pada siswa sekolah dasar. Oleh karena itu, peneliti akan melaksanakan penelitian meta analisis pada jurnal yang sudah sesuai dengan judul yang peneliti ambil. Kemampuan berpikir tingkat tinggi siswa pada tingkat sekolahb dasar. Abrucasto (2012: 12) berpikir kritis merupakan proses yang sudah jelas dan sudah terarah prosesnya yang dapat digunakan sebagai kegiaan pemecahan masalah, menganalisis asumsi - asumsi, dalam pengambilan keputusan, dan juga dapat digunakan sebagai penelitian karya ilmiah. Berpikir kritis adalah sebuah bentuk kemampuan dari Critikal Thingking yang ditujukan untuk siswa agar mampu dalam berpendapat dengan cara yang sistematis dan terorganisi. Berpikir kritis dalam kegiatan pembelajaran dalam suatu kelas juga bertujuan agar siswa mampu menjawab sebuah pertanyaan pertanyaan dengan kritis tidak hanya sekadar menjawab namun juga memperhatikan konsep dan prinsip contohya apa (what), bagaimana (how), mengapa (why). Upaya dalam meningkatkan kemampuan berpikir kritis. Utari (1994: 15) memberikan pendapat bahwa berpikir kritis adalah dapat menciptakan atau memunculkan ide baru untuk menemukan teknik atau produk baru. Bahkan pada pembelajaran matematika selain materi pemecahan masalah ia juga mempunyai arti khusus.

Hasil PISA terbaru membuktikan bahwa kurang memadainya hasil belajar pada pendidikan dasar dan pendidikan menengah hal ini dapat dilihat dari Skor PISA dan peringkat pada tahun 2000 2018. khususnya hasil PISA pada pembelajaran Matematika yang berada pada peringkat 72 dari 78 dengan tingkatan $71 \%$ hal ini membuktikan bahwa tingkat belajar siswa dalam pembelajaran matematika masih berada dibawah tingkat minimum. Berikut ini Grafik Progamme For Internatinal Students Assesment (PISA) 2000 -2018 


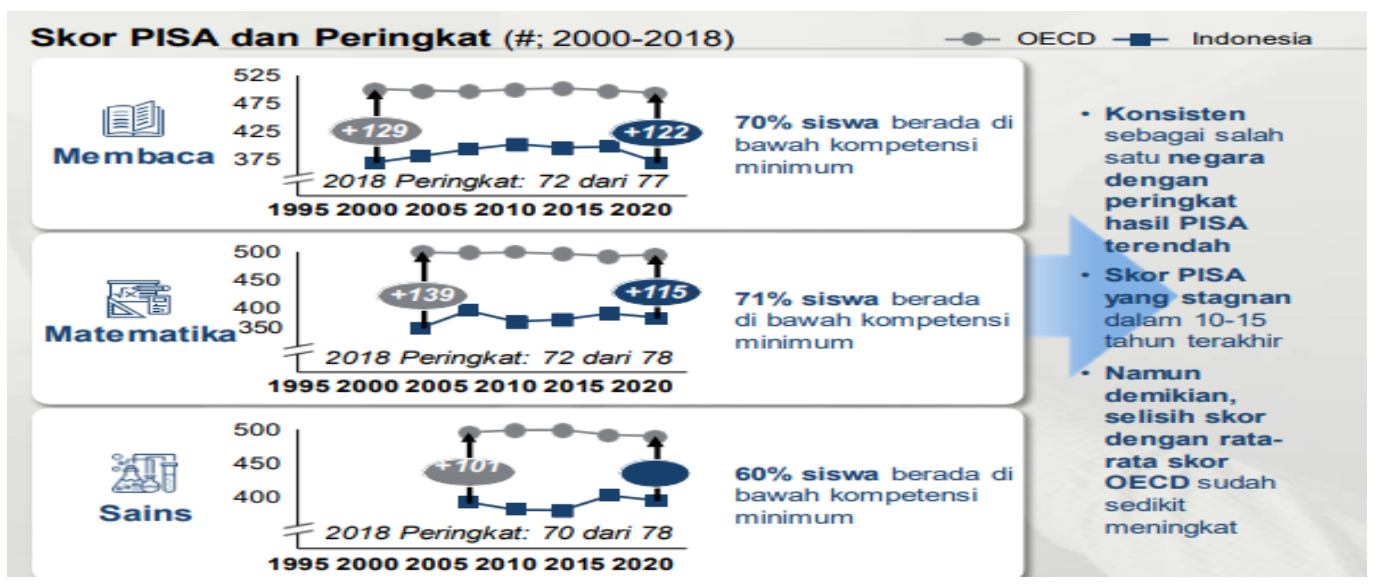

Gambar 1. Grafik PISA sumber dari OECD/PISA, Kearney (2018)

Menurut Abraham dan Niscola (2016: 10) pada umumnya proses pembelajaran disekolah dasar dalam suatu kelas para pendidik masih menggunakan model kontekstual atau ceramah hal ini mengakibatkan peserta didik cenderung merasa bosan dan terlihat pasif saat mengikuti pelajaran dalam suatu kelas. Pada abad ke-21 merupakan peranan penting bagi guru dan siswa untuk memainkan peran sebagai bentuk perubahan dalam kegiatan pembelajaran. Siswa dituntut untuk lebih memiliki pola berpikir kritis, hal ini terdapat dalam 4C yaitu: Critikal Thingking and Problem Solving, Communication, Collaboration, dan Creativity and Innovation. Hal ini terdapat pada keterampilan abad ke-21 (Asnawi, 2013: 5), salah satu keterampilan 4C yang harus dimilik oleh setiap siswa adalah Berpikir Kritis. Maka dari itu pendidik harus menyiapkan pembaharuan model pembelajaran untuk meningkatkan kemampuan siswa dalam berpikir kritis. Keefektivan dengan model yang tepat dalam kemampuan menningkatkan siswa dalam beripikir kritis terhadap pembelajaran matematika (Wulandari, 2013: 16).

Model pembelajaran yang dipilih merupakan model pembelajaran yang berbasis masalah “Problem Based Learning (PBL) Dan Problem Posing Menurut (Siswono, 2005: 158), Problem Based Learning adalah suatu pendekatan pembelajaran yang dimulai dengan mengajukan masalah dan dilanjutkan dengan menyelesaikan masalah tersebut. Untuk menyelesaikan masalah tersebut menurut (Ha Roh, 2008: 14) peserta didik memerlukan pengetahuan baru untuk dapat menemukan solusinya. Adapun 5 sintaks PBL yaitu orientasi masalah, mengorganisasikan, membimbing, mengembangkan, serta menganalisis dan mengevaluasi. Model PBL menuntut peserta didik untuk aktif dalam menyelesaikan masalah dalam materi pembelajaran dan pendidik hanya sebagai fasilitator dalam kegiatan belajar mengajar. Model PBL merupakan morbasis model berbasis masalah yang terfokus pada peserta didik dalam memecahkan masalah pada materi pembelajaran.

Dalam Penelitian As'ari (2005: 8), mengartikan Model Pembelajaran Problem Posing adalah memberikan kesempatan kepada siswa dengan cara penyusunan soal - soal atau merumuskan suatu soal melalui permasalahan atau topik informasi yang diberikan oleh guru. Dengan siswa membuat soal dan menyusun soal sendiri tersebut, pengembangan diri siswa akan terbentuk. Peserta didik akan mampu 
menggunakan konsep konsep yang didapat untuk menyusun soal yang kemudian dapat dikerjakan sendiri atau dikerjakan oleh siswa lain. Bukan hanya kemampuan siswa dalam memecahan masalah namun juga dapat memningkatkan kemampuan siswa dalam 3 ranah yaitu Sikap, pengetahuan dan keterampilan. Adapun 5 sintaks Problem Posing Menurut Thobroni dan Mustofa (2013 :35) yaitu guru memberikan materi, memberikan pelatihan soal, mengajukan atau membuat soal, mengerjakan soal secara acak, dan memberikan tugas secara individu untuk dikerjakan dirumah. Sejalan dengan pendapat Sholimin (2014 :132) bahwa Problem Posing merupakan suatu model pembelajaran yang mewajibkan peserta didik untuk belajar dengan cara pengajuan soal dan pengerjaan soal yang dikerjakan secara mandiri tanpa bantuan dari guru.

\section{METODE}

Jenis penelitian ini merupakan sebuah kajian meta analisis. Menurut Glass (1981) Meta analisis merupakan sebuah analisis kuantitatif dan data yang digunakan pada penelitian meta analisis cukup banyak, dan metode yang di terapkan adalah statistic dengan cara mengorganisasikan beberapa informasi yang berasal dari sampel besar yang berfungsi untuk memenuhi dan melengkapi maksudmaksud lainnya. Sedangkan menurut Sutjipto (1995) meta analisis merupakan salah satu bentuk upaya untuk meringkas atau merangkum berbagai hasil penelitian secara kuantitatif, atau dengan kata lain meta analisis bertujuan untuk menganalisis kembali berbagai hasil penelitian yang sudah dilakukan. Hal ini dilakukan untuk memberikan kajian keajegan atau tidaknya pada sebuah penelitian yang sudah dilakukan. Langkah langkah yang dilakukan peneliti menggunakan metode meta analisis yaitu (1) merumuskan masalah dan tujuan, (2) mencari hasil penelitian-penelitian yang relevan, (3) menganalisis data di dalam penelitian, dan (4) laporan hasil dari penelitian Rahmat Alyakin (2016)

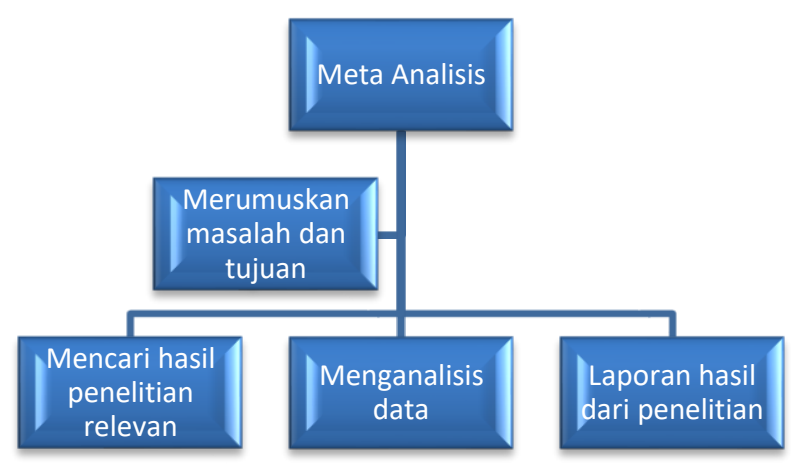

Gambar 2. Road Map Prosedur Meta Analisis

Penelitian yang akan dilakukan oleh peneliti yaitu Perbedaan Model Problem Based Learning dan Problem Posing Terhadap Kemampuan Berfikir Kritis Siswa Sekolah Dasar Pada Pembelajaran Matematika Data penelitian yang akan dikumpulkan dengan cara pencarian artikel atau jurnal ilmiah di google scholaria atau google cendekia. Kata kunci yang digunakan peneliti untuk melakukan penelusuran artikel adalah "Problem Based Learning", "Problem Posing", "Berpikir Kritis".

Data pada penelusuran dengan menggunakan kata kunci di atas seperti "Problem Based Learning", 
"Problem Posing", "Berpikir Kritis" di dapatkan beberapa artikel yang kemudian dipilih artikel atau jurnal yang sudah memenuhi kriteria yang sesuai. Kemudian dalam jurnal atau artikel yang sudah ditemukan dicari data sesudah tindakan dan sebelum tindakan yang tertulis dalam bentuk skor. Selanjutnya skor yang sudah diperoleh dianalisis dengan cara mencari presentase. Tujuan dilakukannya analisis data yaitu untuk mengetahui hasil data dari penelitian yang sudah dilakukan. Pada bagian analisis data ini peneliti menggunakan suatu teknik Komparasi Efektivitas antara Model Pembelajaran Problem Based Learning dan Problem Posing di Tinjau dari Kemampuan Berpikir Kritis Siswa Sekolah Dasar pada Pembelajaran Matematika. Sugiyono (2012: 114) mengemukakan bahwa populasi adalah suatu daerah generalisasi yang mempunyai sebuah objek ataupun subjek yang memiliki tingkatan tingkatan atau ciri tersendiri dan telah ditentukan oleh peneliti agar dapat dipelajari dan dipahami sehingga dapat ditarik sebuah kesimpulan. Populasi yang akan dilaksanakan pada penelitian ini yaitu dengan cara mengumpulkan artikel - artikel yang sudah dipublikasikan dan jurnal dengan tingkatan skala nasional yang terkait dengan judul yang peneliti ambil yaitu Model Problem Based Learning dan Problem Posing Terhadap Kemampuan Berfikir Kritis Siswa SD Pembelajaran Matematika dengan rentang tahun 2011-2020

Instrument pengumpulan data yang akan digunakan pada penelitian ini yaitu lembar pemberian kode. Ada beberapa tahap yang akan digunakan pada lembar pemberian kode tersebut. Lembar pemberian kode data ini juga sangat bermanfaat untuk mendapatkan sebuah informasi. Berikut adalah tahapannya: 1) No Kode, 2) Judul Penelitian yang akan dipakai, 3) Nama Penelitian, 4) Tahun Penelitian yang akan dipakai, 5) Model pada Pembelajaran yang akan digunakan untuk penelitian. Data yang akan diperoleh yaitu berupa lembar pemberian kode yang berisikan sebuah informasi berkaitan dengan artikel dan pengumpulan data seperti tahun akreditasi dan tahun publikasi. Dibawah ini merupakan sebuah instrument pengumpulan artikel berdasarkan pada hasil penelitian yang akan diambil.

Effect Size (besaran efek) yaitu memperlihatkan ada tidaknya perbedaan yang standar antara skor penggunaan model pembelajaran Problem Based Learning dan Problem Posing. Effect Size adalah sebuah satua standar yang memiliki arti dapat untuk digunakan sebagai perbandingan dari beberapa skala yang berbeda-beda dan mampu untuk membandingkan beberapa penelitian-penelitian dengan besaran sampel yang berbeda. Dalam menentukan besaran nilai dari Effect Size ini peneliti menggunakan bantuan dari SPSS 20.00 For Windows. Effect Size yang digunakan peneliti dalam penelitian ini adalah Cohe's $d$, yang bisa diartikan bahwa nilai yang jumlahya semakin besar maka akan semakin besar pula perbedaan antara kedua model pembelajaran Problem Based Learning dan Problem Posing. Berikut ini merupakan interprestasi Effect Size (Cohen, as cited in Becker, 2000)

Tabel 1. Interprestasi Effect Size

\begin{tabular}{|c|c|}
\hline Effect Size & Interprestasi \\
\hline $0<\mathrm{d}<0,2$ & Kecil \\
\hline $0,2<\mathrm{d} \leq 0,5$ & Sedang \\
\hline $0,5<\mathrm{d} \leq 0,8$ & Besar \\
\hline $\mathrm{d}>0,8$ & Sangat Besar \\
\hline
\end{tabular}




\section{HASIL DAN DISKUSI}

Hasil penelitian yang didapatkan dari 20 artikel yang terkait dengan model pembelajaran Problem Based Learning dan Problem Posing dengan masing masing jurnal berjumlah 10 dengan ketentuan jurnal telah dipublikasikan secara nasional. Dalam penelitian ini peneliti mengacu terhadap kategori teknik pengumpulan data yang dilakukan yaitu yang pertama menggunakan artikel yang terbit pada 10 Tahun terakhir atau kisaran tahun 2011-2020 yang berjumlah 20 jurnal. yang kedua peneliti menemukan masing-masing 10 jurnal terhadap dua model pembelajaran yang akan digunakan. Dimana 10 jurnal yang pertama sesuai judul peneliti yaitu model pembelajaran Problem Based Learning Terhadap Kemampuan Berfikir kritis pada pembelajaran Matematika Sekolah Dasar dan 10 jurnal lagi sesuai dengan judul yang akan peneliti ambil yaitu model pembelajaran Problem Posing Terhadap Kemampuan Berfikir Kritis Matematika Sekolah Dasar. Yang ketiga Sampel yang akan digunakan pada penelitian ini adalah jenjang Sekolah Dasar (SD). Langkah yang terakhir yaitu lingkup wilayah yang akan digunakan pada penelitian ini adalah wilayah atau kawasan Indonesia. Hasil penelitian ini kemudian dikelompokkan menurut sub-unit analisis. Pengelompokkan ini bertujuan untuk dapat mempermudah peneliti untuk menganalisis hasil data. Seperti yang sudah dikemukakan oleh Glass (1981) bahwa meta analisis adalah analisis yang bersifat kuantitatif dengan menggunakan sejumlah data yang besar yang ditujukan untuk melakukan analisis kembali dari hasil penelitian yang sudah diolah secara statistic berdasarkan dari pengumpulan data penelitian yang bersifat primer.

Tabel 2. Presentase Peningkatan Kemampuan Berpikir Kritis Pembelajaran Matematika Dengan

Model Pembelajaran Problem Based Learning

\begin{tabular}{|c|c|c|c|c|}
\hline \multirow{2}{*}{ No } & \multirow{2}{*}{ Kode Data } & \multicolumn{3}{|c|}{ Presentase (\%) } \\
\cline { 3 - 5 } & & Skor Pretest & Skor Posttest & Peningkatan \\
\hline 1 & 1B & 74,6 & 80,6 & 6 \\
\hline 2 & 2B & 67,48 & 79,23 & 11,75 \\
\hline 3 & 3B & 77.59 & 81,74 & 4,15 \\
\hline 4 & 4B & 66.72 & 76.88 & 10,16 \\
\hline 5 & 5B & 56,36 & 74,97 & 18,61 \\
\hline 6 & 6B & 53,61 & 81,94 & 28,33 \\
\hline 7 & 7B & 14 & 24,8 & 10,8 \\
\hline 8 & 8B & 63 & 80,25 & 17,25 \\
\hline 9 & 9B & 63,5 & 84,25 & 20,75 \\
\hline 10 & 10B & 59,40 & 78,96 & 19,56 \\
\hline & Rata-rata & 59,63 & 74,36 & 14,73 \\
\hline
\end{tabular}

Presentase pada rata - rata peningkatan kemampuan berpikir kritis pada pembelajaran Matematika menggunakan model pembelajara Problem Based Learning dari skor terendah adalah 4,15\%, skor tertinggi $28,33 \%$ dan rata rata pada peningkatan ini sebesar $14,73 \%$. Presentase rata-rata pada skor pretest menggunakan model Problem Based Learning sebesar 59,63\%, Presentase rata-rata skor posstest menggunakan model Problem Based Learning sebesar 74,36\%. Presentase rata-rata sesudah dan sebelum menggunakan model pembelajaran Problem Based Learning mengalami sebuah peningkatan 
sebesar $14,73 \%$.

Tabel 3. Presentase Peningkatan Kemampuan Berpikir Kritis Pembelajaran Matematika dengan Model Pembelajaran Problem Posing

\begin{tabular}{|c|c|c|c|c|}
\hline \multirow{2}{*}{ No } & \multirow{2}{*}{ Kode Data } & \multicolumn{3}{|c|}{ Presentase (\%) } \\
\cline { 3 - 5 } & & Skor Pretest & Skor Posttest & Peningkatan \\
\hline 1 & $1 \mathrm{P}$ & 55 & 62,5 & 7,5 \\
\hline 2 & $2 \mathrm{P}$ & 70,43 & 87.18 & 16,75 \\
\hline 3 & $3 \mathrm{P}$ & 47,76 & 77,13 & 29.37 \\
\hline 4 & $4 \mathrm{P}$ & 49,78 & 75,66 & 25,88 \\
\hline 5 & $5 \mathrm{P}$ & 62,87 & 84,43 & 21,56 \\
\hline 6 & $6 \mathrm{P}$ & 66 & 83,54 & 17,54 \\
\hline 7 & $7 \mathrm{P}$ & 44,68 & 66,28 & 21,6 \\
\hline 8 & $8 \mathrm{P}$ & 41,33 & 61,77 & 20,44 \\
\hline 9 & $9 \mathrm{P}$ & 64,3 & 82,86 & 18,56 \\
\hline 10 & $10 \mathrm{P}$ & 67,32 & 81,23 & 13,91 \\
\hline & Rata-rata & 56,95 & 76,26 & 19.31 \\
\hline
\end{tabular}

Presentase rata-rata peningkatan kemampuan berpikir kritis menggunakan model pembelajaran Problem Posing dari skor terendah sebesar 7,5\%, skor tertinggi sebesar 29,37\%, dan skor rata rata sebesar $19,31 \%$. Presentase rata - rata terhadap kemampuan berpikir kritis pembelajaran matematika sebelum menggunakan model pembelajaran Problem Posing sebesar 56,95\%, presentase rata - rata sesudah menggunakan model pembelajaran Problem Posing sebesar 76,26\%. Presentase rata-rata sesudah dan sebelum dengan menggunakan model pembelajaran Problem Posing mengalami peningkatan sebesar $19,31 \%$.

Tabel 4. Komparasi Pengukuran Kemampuan Berpikir Kritis Pembelajaran Matematika

\begin{tabular}{|c|c|c|c|}
\hline \multirow{2}{*}{ Pengukuran } & \multicolumn{3}{|c|}{ Rata-Rata Skor (Mean) } \\
\cline { 2 - 4 } & Problem Based Learning & Problem Posing & Selisih \\
\hline Pretest & $59.626 \%$ & $56.95 \%$ & $2,68 \%$ \\
\hline Posstest & $74.362 \%$ & $76.26 \%$ & $1.90 \%$ \\
\hline
\end{tabular}

Sesuai dengan hasil pengukuran pada komparasi rata-rata skor pada data tabel diatas, rata - rata skor pretest pada model pembelajaran Problem Based Learning dan Problem Posing mempunyai selisih sebesar 2,68\%, sedangkan pada rata-rata skor nilai posstest antara model pembelajaran Problem Based Learning dan Problem Posing mempunyai selisih sebesar 1,90\%.

Pada diagram 1 berikut dapat dilihat bahwa terdapat peningkatan dari skor pretest dan posstest pada model pembelajaran Problem Based Learning dan Problem Posing. Uji Ancova dilakukan yang bertujuan untuk dapat mengetahui ada tidaknya perbedaan yang sangat signifikan diantara penggunaan kedua model pembelajaran Problem Based Learning dan Problem Posing terhadap kemampuan berpikir kritis pembelajaran matematika pada siswa sekolah dasar. Berikut ini merupakan tabel dari hasil analisis uji Ancova. 


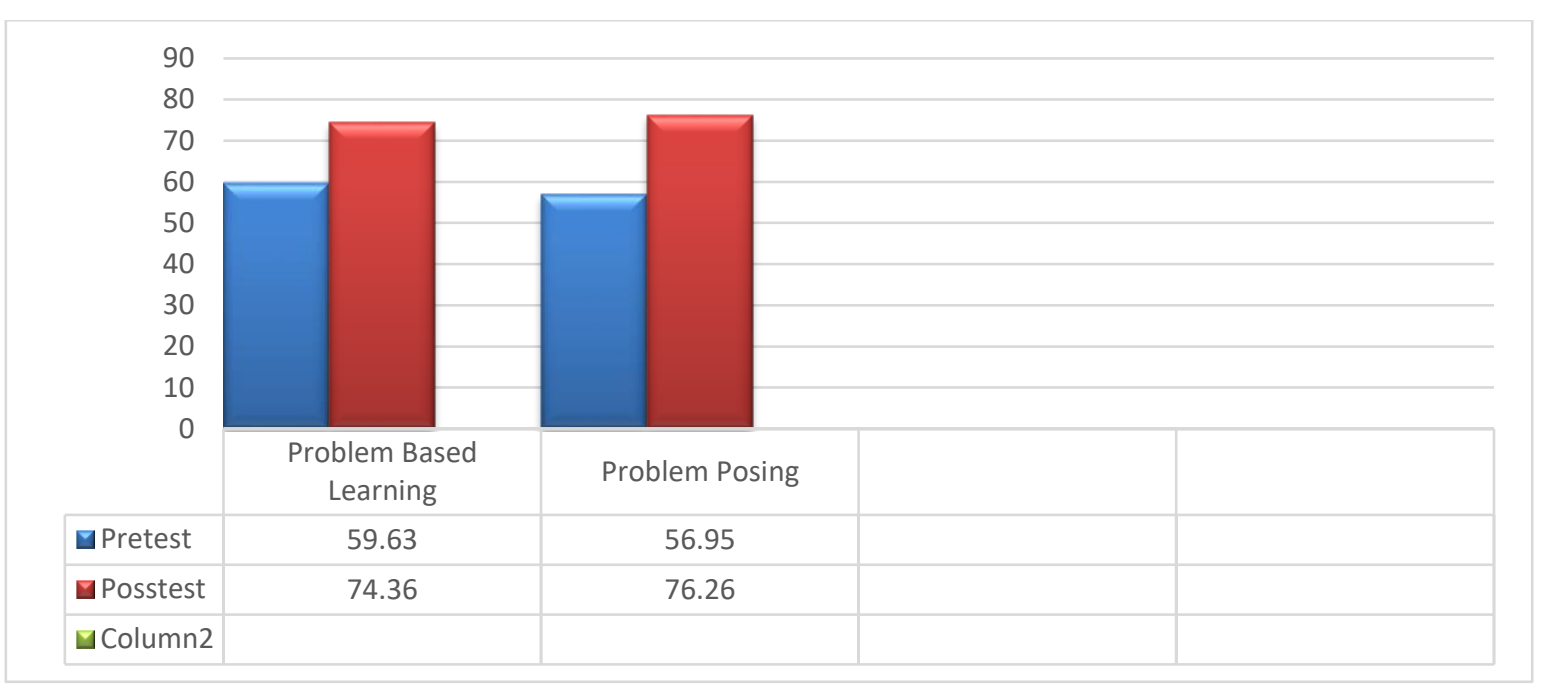

Diagram 1. Diagram Komparasi Data Antara model pembelajaran Problem Based Learning dan Problem Posing

Tabel 5. Hasil Analisis Data Menggunakan Uji Ancova

Dependent Variable: POSTEST

\begin{tabular}{|l|r|r|r|}
\hline \multicolumn{1}{|c|}{ MODEL_PEM } & \multicolumn{1}{|c|}{ Mean } & Std. Deviation & N \\
\hline MODEL PBL & 74.3620 & 17.61046 & 10 \\
MODEL PP & 76.2580 & 9.47083 & 10 \\
Total & 75.3100 & 13.79626 & 20 \\
\hline
\end{tabular}

Pada tabel 5, sesuai dengan hasil analisis data yang sudah dilakukan oleh peneliti menggunakan uji Ancova yang dilakukan menggunakan model pembelajaran Problem Based Learning yang memiliki jumlah artikel sebanyak 10 dengan rata-rata 74,3620. Sedangkan pada model pembelajaran Problem Posing dengan jumlah artikel yang sama yaitu sebanyak 10 dan mempunyai rata-rata 76,2580. Sehingga dari hasil yang sudah didapatkan tersebut terdapat suatu perbedaan antara kedua model pembelajaran Problem Based Learning dan Problem Posing ditinjau dari peningkatan kemampuan berpikir kritis pada pembelajaran matematika. Model pembelajaran Problem Posing lebih tinggi dibandingkan dengan model pembelajaran Problem Based Learning. Hasil ini sejalan dengan penelitian yang dilakukan oleh Wahyu Wulandari \& Wahyudi (2020) bahwa terdapat kemampuan dalam berpikir kritis dari model pembelajaran Problem Solving dan Problem Posing terhitung lebih efektif model pembelajaran Problem Posing untuk dapat meningkatkan kemampuan berpikir kritis matematika siswa sekolah dasar dibandingkan dengan model Problem Solving. Hal ini terbukti dari nilai hasil rerata posstest yang memperoleh jumlah sebesar 87,1 dengan peningkatan sebesar 17\%. Dan untuk nilai N-Gain mengalami peningkatan sebesar 0,57. Sedangkan untuk model pembelajaran Problem Solving hanya memperoleh nilai hasil rerata sebesar 79,7 dengan tingkat peningkatan sebesar $15 \%$ dan nilai N-Gain mengalami peningkatan sebesar 0,43. Dengan demikian, dapat menguatkan bahwa model pembelajaran Problem Posing lebih efektif dalam meningkatkan kemampuan berpikir kritis terhadap pembelajaran matematika siswa Sekolah Dasar. 
Tabel 5. Hasil Analisis Uji Ancova

Dependent Variable: POSTEST

\begin{tabular}{|l|r|r|r|r|r|r|}
\hline Source & \multicolumn{1}{|c|}{$\begin{array}{c}\text { Type III Sum } \\
\text { of Squares }\end{array}$} & Df & Mean Square & F & \multicolumn{1}{c|}{ Sig. } & \multicolumn{1}{c|}{$\begin{array}{c}\text { Partial Eta } \\
\text { Squared }\end{array}$} \\
\hline Corrected & $2853.831^{\mathrm{a}}$ & 2 & 1426.915 & 31.810 & .000 & .789 \\
Model & 664.147 & 1 & 664.147 & 14.806 & .001 & .466 \\
Intercept & 2835.857 & 1 & 2835.857 & 63.220 & .000 & .788 \\
PRETEST & 87.700 & 1 & 87.700 & 1.955 & .180 & .103 \\
MODEL_PEM & 762.569 & 17 & 44.857 & & & \\
Error & 117048.321 & 20 & & & & \\
Total & 3616.399 & 19 & & & & \\
Corrected Total & & & & & \\
\hline
\end{tabular}

a. R Squared $=.789($ nAdjusted $\mathrm{R}$ Squared $=.764)$

Sesuai dengan hasil uji Ancova yang sudah terdapat didalam kolom model pembelajaran tabel diatas, maka dapat ditarik kesimpulan bahwa tingkat signifikasi pada kolom Sig. sebesar 0,000. F hitung yang sudah diperoleh adalah 31.810 dan $\mathrm{F}$ tabel yang sudah terdapat dari perolehan data diatas adalah 3,59 didapatkan dengan cara menggunakan rumus df1=k-1 df1=3-1 df1=2, df2=n-k, df2=20-3, df $2=17$. Untuk dapat menemukan hasil 3,59 terdapat pada $\mathrm{F}$ tabel yang di atur dan di sesuaikan berdasarkan dengan jumlah sampel dan dikurangkan dengan jumlah variable (variable bebas dan terikat), sehingga dapat ditemukan hasil 3,59.

Sesuai dengan tabel diatas yang melakukan uji Effect Size dengan menggunakan uji Ancova menggunakan model pembelajaran Problem Based Learning dan Problem Posing. Dalam penelitian tersebut terdapat hasil yang terlihat pada tabel kolom Corrected Model yang dapat diketahui dari Partial Eta Squared yakni dengan jumlah sebesar 0,789 dengan nilai Sig. sebesar 0,000. Hal ini dapat menunjukkan bahwa model pembelajaran Problem Based Learning dan Problem Posing dapat memberikan pengaruh tergolong besar terhadap kemampuan berpikir kritis pada pembelajaran matematika siswa sekolah dasar. Hal ini sejalan dengan penelitian yang dilakukan oleh Sri Hastuti Noer (2018) dalam penelitiannya yang menunjukkan bahwa pembelajaran dengan menggunakan model Problem Based Learning dan Problem Posing sangat efektif dan memberikan pengaruh yang besar, hal ini dapat dibuktikan dari nilai Effect Size yang dihitung dengan menggunakan Uji Ancova yaitu melalui Partial Eta Squared dengan jumlah sebesar 0,711 dengan nilai Sig. sebesar 0,005. Dengan demikian, dapat menguatkan, bahwa model pembelajaran Problem Posing dan Problem Based Learning sama sama memberikan pengaruh yang besar terhadap kemampuan berpikir kritis pada pembelajaran matematika siswa Sekolah Dasar.

\section{KESIMPULAN}

Penelitian ini bertujuan untuk mengetahui perbedaan komparasi keefektifan model pembelajaran Problem Based Learning dan Problem Posing untuk meningkatkan kemampuan Berpikir Kritis pada pembelajaran Matematika siswa Sekolah Dasar menggunakan metode meta analisis. Pernyataan ini 
mampu dibuktikan dengan mengetahui hasil uji Ancova yang menunjukkan nilai rata - rata pada skor posstest terhadap model pembelajaran Problem Posing sebesar 76,2580 hasil tersebut lebih besar jumlahnya dibandingkan dengan skor rata-rata nilai posstest terhadap model pembelajaran Problem Based Learning yaitu dengan jumlah 74,3620. Sejalan dengan hasil uji Ancova maka dapat ditentukan bahwa dengan menggunakan model pembelajaran tipe Problem Posing lebih efektif dibandingkan dengan model pembelajaran tipe Problem Based Learning. Berdasarkan dengan taksiran, Effect size yang dietahui dari Partial Eta Squared yang menunjukkan skor hasil dengan jumlah 0,789 dan dengan skor Sig. sebesar 0,000. Dari hasil yang sudah di temukan dan dibuktikan bahwa kedua model pembelajaran Problem Based Learning dan Problem Posing mampu memberikan pengaruh yang tergolong Besar untuk meningkatkan kemampuan berpikir kritis terhadap pembelajaran matematika siswa sekolah dasar.

\section{UCAPAN TERIMA KASIH}

Yang pertama peneliti mengucapkan puji syukur kepada Allah SWT yang telah memberikan kelancaran dalam menyelesaikan artikel ini. Yang kedua ucapan terimakasih kepada kedua orang tua yang telah memberikan dukungannya selalu. Kemudian terimakasih kepada dosen pemimbing Dra. Endang Indarini, M. Pd yang telah membimbing dan mengarahkan dalam proses penyelesaian artikel ini serta ucapan terimakakasih kepada saudara dan para teman-teman yang telah memberikan semangat dan dukungan.

\section{REFERENSI}

Anugraheni, I. (2018). Pengembangan Perangkat Pembelajaran Matematika Berbasis Pendidikan Karakter Kreatif di Sekolah Dasar. Refleksi Edukatika, 8(2).

Arifin, Zainal. (2014). Evaluasi Pembelajaran. Bandung: PT Remaja Rosdakarya.

Astuti, W. P. (2018). Efektivitas Model Pembelajaran Problem Based Learning dan Problem Solving Terhadap Kemampuan Berpikir Kreatif Matematika Peserta didik Kelas 4. Jurnal Imiah Pendidikan Dan Pembelajaran, 2(2), 159-166. https://doi.org/10.23887/jipp.v2i2.15349.

Dahar, R. W. (2011). Teori-Teori Belajar dan Pembelajaran. Jakarta: Erlangga.

Dewi, T. A., \& Wardani, N. S. (2018). Upaya Peningkatan Keterampilan Pemecahan Masalah Matematika Melalui Pendekatan Problem Based Learning. Widyagogik, 6(1), 1-12.

Dwi, Afnan Puji Astuti, Slameto, E. W. S. (2018). Pengaruh Penerapan Model Problem Posing Terhadap Kemampuan Pemecahan Masalah Peserta Didik Kelas IV SD. Didaktika Dwija Indria, $6(3), 82-89$. 
Faizah, U. (2015). Penerapan Pendekatan Saimtifik Melalui Model Project Based Learning Untuk Meningkatkan Keterampilan Proses Dan Hasil Belajar Peserta Didik Kelas IV SD Negeri Seworan, Wonosegoro. Jurnal Scholaria, 5(1), 24-38.

Gd. Gunantara, Md. Surjana, P. N. R. (2014). Penerapan Model Pembelajaran Problem Based Learning untuk Meningkatkan Kemampuan Pemecahan Masalah Matematika Peserta Didik Kelas V. Quality, 2, 1-29.https://doi.org/10.1073/pnas.0703993104.

Gulo, W. (2002). Strategi Belajar Mengajar. Jakarta: PT. Grasindo.

Haji, S. (2010). Pendekatan Problem Posing Dalam Pembelajaran Matematika di Sekolah Dasar. Kependidikan Triadik, 5(1412), 1-72. 118

Heruman. 2014. Model Pembelajaran Matematika. Bandung: PT Remaja Rosdakarya.

Hidayat A. dan Irawan I. (2017). Pengembangan LKS Berbasis RME Dengan Pendekatan Problem Solving untuk Memfasilitasi Kemampuan Pemecahan Masalah Matematis Peserta Didik. Journal Cendekia: Jurnal Pendidikan Matematika, 1(2), 51-63.

Hosnan, M. (2014). Pendekatan saintifik dan kontekstual dalam pembelajaran abad 21: Kunci sukses implementasi kurikulum 2013. Ghalia Indonesia.

Indarwati, D., Wahyudi, W., \& Ratu, N. (2017). Peningkatan Kemampuan Pemecahan Masalah Matematika Melalui Penerapan Problem Based Learning untuk Peserta Didik Kelas V Sd. Satya Widya, 30(1), 17. https://doi.org/10.24246/j.sw.2014.v30.i1.p17-27.

Kemendikbud. (2016). Permendikbud Nomor 22 Tahun 2016 Tentang Standar Proses Pendidikan Dan Menengah. Jakarta: Kemendikbud

Komariah, K. (2011). Penerapan Metode Pembelajaran Problem Solving Model Polya untuk Meningkatkan Kemampuan Memecahkan Masalah Bagi Peserta didik Kelas IX J Di SMPN 3 Cimahi. Prosiding Seminar Nasional Penelitian, Pendidikan Dan Penerapan MIPA, Fakultas MIPA, Universitas Negeri Yogyakarta, 1, 1.

Kosasih, E. (2014) Strategi Belajar dan Pembelajaran Implementasi Kurikulum 2013. Bandung: Yrama Widya.

Listiani, Riska., Hidayat, Ara., \& Maspuah, Meti. Perbandingan Model Pembelajaran Problem Solving dan Poblem Based Learning Terhadap Hasil Belajar Siswa Pada Materi Sistem Reproduksi Manusia. Jurnal Program Studi Pendidikan Biologi. 7(1). 
Meta Analisis Efektivitas Model Problem Based Learning dan Problem Posing Terhadap Kemampuan Berpikir Kritis Siswa

Sekolah Dasar Pada Pembelajaran Matematika, Jaya Yanti Nur Istiqomah, Endang Indarini

Maarif, H. (2015). Eksperimentasi Problem Based Learning dan CIRC dalam Menyelesaikan Soal Cerita Matematika Peserta Didik Kelas 5 SD Pendidikan Guru Sekolah Dasar - FKIP - UKSW Salatiga. Scholaria: Jurnal Pendidikan Dan Kebudayaan, 97-115.

Musfiqon. (2012). Metodologi Penelitian Pendidikan. Jakarta: PT. Prestasi Pustakarya.

Wulandari, W dan Wahyudi. (2020). Efektivitas Model Pembelajaran Problem Solving dan Problem Posing ditinjau dari Kemampua Berpikir Kritis Matematika Siswa Kelas 4Jurnal $\quad$ Sekolah Dasar, 5 (01), 1-1. 